\title{
Analysis on the Cultivation of College Students' Autonomous Learning Ability in College English
}

\author{
Liu Li \\ Art \& Literature College of Xi'an International University, Xi'an, Shaanxi, China 710077 \\ yhllzz@126.com
}

Keywords: Cultivation, College Students' Autonomous Learning Ability, College English

\begin{abstract}
Today, with the rapid development of science and technology and the rapid development of society, for social individuals, lifelong learning is no longer a matter of choice, but a problem of survival, and the ability to learn independently becomes more and more important. As in other fields, the language education community is paying more and more attention to independent learning. This paper focuses on the concept of "self-learning" in English learning, the importance of cultivating students' self-learning ability, and the necessity of self-study, and proposes relevant ways and methods of cultivating self-learning ability.
\end{abstract}

\section{Introduction}

The cultivation of self-learning ability is not only a content of college English reform, but also a very important aspect of higher education. Since the 1980s, many educators have begun to focus on autonomous learning and begin research. Littlewood believes that autonomous learning should be seen as an important and clear goal in all learning, because teachers can't accompany and guide learners' lifelong learning. The author believes that in college English education, teachers fully recognize the importance of independent learning, and cultivating students' independent learning ability is an inevitable trend of our foreign language teaching reform.

\section{The Concept of "Self-learning"}

Many scholars have studied and discussed the content of autonomous learning in different aspects: (eg Dickinson, 1993; Littlewood, 1999; etc.). HenriHolec was the first to introduce the concept of "self-learning" into the teaching of foreign languages in universities. Holec believes that for learners, self-learning means that learners can "respond to their own learning" in the process of learning, which is to effectively solve various problems encountered in learning. Holec believes that the decision-making activities to solve this problem are mainly manifested in the following five points: (1) the determination of relevant learning objectives; (2) a learning content and the decision of learning progress in the learning process; (3) the current learning objectives adopted What kind of learning method is used for learning; (4) Really monitor the progress of the state of the learning; (5) Finally, make a learning effect evaluation on the things that are learned. "Self-learning" strengthens the transfer of a learning responsibility from the teacher to the student, and encourages the student to gradually detach from the dependence on the teacher in the process of learning. Its theoretical basis is cognitive psychology and humanistic psychology. Dickinson sees this autonomy as an attitude toward language learning. LittleWood also defines student autonomy as not relying on teachers in the learning process, but on using knowledge of what they have learned to develop a comprehensive ability. Chen Dongchun reviewed the reasons for independent learning and analyzed some of the necessary starting conditions. For a university student with certain self-learning ability, the independent learning of English is defined as follows: Self-study means that students rely on their unique Learning ability, positive learning attitude and good study habits, can set a learning goal independently or only under the guidance of the teacher, and plan the learning through their own activities and cooperation with others. Implementation, learning objectives, assessment of learning 
outcomes, and learning process to achieve learning goals. In other words, self-directed learning is self-monitoring learning, which can be divided into three different aspects: First, the task of learning should first plan the learning activities; second, always monitor their actual learning activities and Make corresponding evaluations and give corresponding opinions. Third, in the face of shortcomings in learning activities, you should adjust your learning activities in a timely manner. Autonomous learning actually means that students can select, control and adjust their learning activities according to their own objective conditions.

\section{The Importance and Necessity of Cultivating Students' Self-Learning Ability}

Under the influence of long teaching methods and traditional teaching models, both teaching and learning are severely restricted. Therefore, one of the reasons why the effect of college English teaching is not ideal is that most of the current college English teaching adopts "teaching" teaching. This teaching method does not give full play to the enthusiasm of students' independent learning, but overemphasizes the teacher's knowledge transfer during the class. At present, the foreign language teaching method in China mainly adopts the teacher-led classroom knowledge-based teaching mode--from the selection of teaching materials, learning content, learning progress, and evaluation of grades, all of which are determined by teachers, it is difficult to take into account students' English learning. Therefore, under the influence of this teaching mode for a long time, students' learning autonomy, enthusiasm and creativity are difficult to fully exert, and independent and independent learning ability is difficult to cultivate, which seriously affects the benign development of foreign language teaching and reduces the effect of teaching.

Foreign language teaching should aim to cultivate students' love of language and make it a successful language learner, rather than relying entirely on teachers. Education should closely combine the teaching of teachers with the students' learning, and cultivate students' independence so that students can learn English independently and independently. Therefore, an important purpose in foreign language teaching is to cultivate students' self-learning ability, and gradually get rid of the teacher's full help through independent learning, and finally achieve independent learning and mastering a language. For students to learn, it is impossible to really master the language by studying in the classroom textbook. Students must learn to accept and consume more language information after class, find more opportunities to use the language, and improve their ability to master the language through practical application.

Through research, there are many reasons that affect students' foreign language learning, such as the personality traits, the gender of learners, the cognitive styles of things, the motivation of learning, and Learn about the various strategies used in learning strategies and interests. In recent years, through the practice of teaching foreign language education, we have gradually realized that the theoretical reforms of our educational methods are often inversely proportional to the effects we are trying to achieve. Individual differences in learners' hobbies, personality, motivation, intelligence, and methodological strategies of learning all determine that foreign language education cannot use the same teaching method for each student, shaping them into a look; Individuals' own talents and acquired efforts are not the same. Even students in a class have commonalities and differences. Therefore, teachers must adjust their teaching plans according to this actual situation and take care of them. Most of them can take care of a small number of students and teach them in accordance with their aptitude. At the same time, the university period is the golden age of students' intellectual development. College students' self-learning has its favorable conditions - psychological and physiological maturity and a relatively high level of thinking and independent consciousness. In addition, many objective factors such as the progress requirements of college English teaching also make many problems of students not rely too much on teachers to answer during class. Students must have certain ability to learn independently, according to their own situation and learning characteristics. As well as learning hobbies to develop a plan that suits your own learning, and reasonable arrangements for study time.

The ability of individuals to adapt to the environment and adapt to change has a pivotal position in 
the context of globalization. At the same time, with the popularization of higher education, the college students who are studying are showing an increasing trend every year. In contrast, the teachers are relatively insufficient, which leads to the discussion between teachers and students. Less and less, this makes the task of cultivating students' independent learning ability more urgent.

\section{Measures to Cultivate and Improve "Self-learning" Ability}

Most of the freshmen who have entered the university campus from the high school stage are faced with the problem of not being used to the learning environment, not adapting to teaching methods, and not understanding the characteristics and methods of learning. Some students adapt to exam-oriented education and are accustomed to relying on teachers. As a college English teacher, you should understand the students' thoughts in the teaching process, help students adjust their learning psychology as early as possible through lectures and questionnaires, and encourage students from psychological and spiritual aspects to help students maintain a good attitude in the process of English learning. Form good study habits, help them to switch from high school learning habits, and adapt to college English learning methods as soon as possible. At the same time, make full use of multimedia information technology and networks to continuously improve and update teaching content and teaching methods. For example, pre-study the students to prepare the texts, understand the relevant background, arrange the presentation tasks in groups, and let the students use the music, pictures and movies to introduce the background, introduce the texts, and arouse the students' perceptual knowledge and interest in the texts; , scenario simulation, etc. for listening, speaking, writing and other training. These practices can enhance students' awareness of participating in the classroom, make students become the main body of English class and can experience the fun of English learning, improve students' self-confidence and consciousness, thus generate the motivation of independent learning and improve the awareness of independent learning.

English is a language practice class. Students' language skills can only be cultivated and improved through language practice, which depends to a large extent on students' subjective initiative and participation. In college English classroom teaching, teachers should strive to create a dynamic teaching atmosphere and form a good independent learning environment, which is very important for cultivating and improving students' English self-learning ability. Teachers can select language materials around a theme, develop teaching content, create a large number of participatory activities and situations, and make the English classroom a place for students' language practice. For example, a teacher can ask questions about the readable content in the text, let the students read the questions, organize the answers, and discuss the questions covered in the tutorial. You can also design performances, contests, or commentary programs for the content of the text, and add some discussion, discussion, and debate-style teaching activities to allow students to express their opinions independently after thinking or discussing. This greatly mobilizes students' enthusiasm, subjective initiative and participation, so that students can actively and actively use language to practice through pre- or post-class preparation, individual efforts or collective cooperation, truly become the main body of teaching activities, and finally achieve training and improvement.

Teaching is the process of interaction between teaching and learning. It is a complete teaching system composed of teachers' teaching and students' learning. Teachers should pay attention to teaching methods, and study the learning methods of students to help students find learning methods that suit their own characteristics. College English teaching should not only enable students to master basic language knowledge, but also teach students how to learn, so that students learn to learn to develop their language independent learning ability. It is necessary to combine students' existing knowledge level and cognitive ability, encourage them to actively research and discover, and cultivate their ability to think, collect, organize, summarize, analyze and process information independently, and broaden the time and space of their independent learning. Teachers can guide students to develop their own long-term and near-term learning goals by analyzing the syllabus of college English, the specific requirements and goals of each semester, and the needs and learning levels of individual self-learning. Teachers should conduct targeted strategy guidance and training for 
students at different levels of the class. For example, teachers organize students to summarize and evaluate the learning strategies they have used in completing language activities, and point out the students' deficiencies according to their own observations, so as to introduce new learning strategies in a timely manner, and let other students propose according to their actual situation. Some English learning strategies that suit you. Through this series of monitoring, assessment and learning strategy adjustment activities, students' self-learning ability can be continuously improved.

In the information society, computer science and the Internet are well known. At the same time, the use of multimedia technology in college English teaching is becoming more and more popular. The traditional teaching methods can no longer meet the needs of the new era development, which puts forward higher requirements for improving the quality of college English teaching, and also provides students with a more convenient and fast learning path. The application of network technology in college English teaching can quickly and effectively stimulate students' strong desire for knowledge, broaden the knowledge level of teaching, make teaching more scientific and rigorous, and keep pace with the development of the times.

\section{Conclusion}

How to cultivate students' self-learning ability is a very important research topic in foreign language teaching and a long-term goal of foreign language teaching. Therefore, it is necessary for teachers to take students as the main body in college English teaching, create appropriate learning environment and conditions, continuously cultivate students' ability and enthusiasm to participate in classroom learning, systematically train students' learning methods, and cultivate students' self-directed learning consciousness. Improve the ability to learn independently.

\section{References}

[1] Dickinson, L. Talking Shop: Aspects of Autonomous Learning. An Interview with Leslie Dichinson. ELT Journal, 2003.47(4):330-335.

[2] Holec H. Autonomy and Foreign Language Learning [M].Oxford: Pergamon Press, 2011.

[3] Littlewood W. Defining and Developing Autonomy in East Asian Contexts. Applied Linguistics, 2009(1):71-94.

[4] Chen Dongchun. On the Orientation of Self-directed Learning in College English Teaching in China [J]. Foreign Languages, 2006(3).

[5] Peng Jinding. Research on "Learner Autonomy" in College English Teaching [J]. Foreign Language World, 2002. 